\title{
Swimming rate and responses of larvae of three mactrid bivalves to salinity discontinuities*
}

\author{
Roger Mann ${ }^{1}$, Bernardita M. Campos ${ }^{2}$, Mark W. Luckenbach ${ }^{1}$ \\ ${ }^{1}$ School of Marine Science, College of William and Mary, Virginia Institute of Marine Science, Gloucester Point, \\ Virginia 23062, USA \\ ${ }^{2}$ Instituto de Oceanologia, Universidad de Valparaiso, Casilla 13-D, Vina Del Mar, Chile
}

\begin{abstract}
Straight-hinge, umbo and pediveliger larvae of the mactrid bivalves Spisula solidissima, Mulinia lateralis and Rangia cuneata were exposed to intense salinity discontinuities of $0,5,10$ and $15 \%$ in vertically oriented swimming chambers. Larvae concentrated in the region of highest gradient, i. e. at the salinity discontinuity, regardless of species, stage of development or larval brood. S. solidisima larvae, initially swimming at $30 \%$ salinity, crossed discontinuities of both 5 and $10 \%$ but not of $15 \%$. M. lateralis larvae, initially swimming at $25 \%$ salinity, also crossed a discontinuity of $5 \%$ but not of 10 or $15 \%$. $R$. cuneata larvae, initially swimming at $10 \%$ salinity, generally preferred to remain at that salinity. Swimming and passive sinking velocities, defined as vertical distance traversed per unit time, were measured in different salinities under constant temperature and light. For all species, swimming rate changed with larval stage, highest velocity occurring at the umbo stage. Upward swimming rate of S. solidissima larvae ranged from 0.18 to $0.49 \mathrm{~mm} \mathrm{~s}^{-1}$ and increased with increasing salinity. Upward swimming rate of $M$. lateralis larvae ranged from 0.25 to $0.50 \mathrm{~mm} \mathrm{~s}^{-1}$, but was not consistently related to salinity. Upward swimming rate of $R$. cuneata larvae ranged from 0.18 to $0.53 \mathrm{~mm} \mathrm{~s}^{-1}$; swimming rate of pediveliger larvae increased consistently as salinity decreased. Downward swimming rates were similar to upward rates. No significant differences in downward swimming rate were detected in relation to salinity. Passive sinking was more frequent than active downward swimming in umbo and pediveliger larvae. Sinking rate increased with larval size of $S$. solidissima and $M$. lateralis larvae; however, $R$. cuneata straight-hinge larvae sank faster than umbo and pediveliger larvae. Species-specific differences in larval sinking and swimming are related to the different habitats occupied by adults. Larvae of $S$. solidissima, a marine stenohaline species, remained in high salinity water. Larvae of $M$. lateralis, a euryhaline species, use their preference for discontinuities or higher salinity water to assist retention in partially mixed estuaries. High sinking rate and short larval period of $R$. cuneata may offset the behavioural characteristic and aid in the retention of $R$. cuneata larvae in the low salinity zone of most partially mixed estuaries.
\end{abstract}

\section{INTRODUCTION}

Larvae of bivalve molluscs can be a major component of the merozooplankton and exhibit large spatial and seasonal fluctuations in abundance (Thorson 1950). Dispersal of most estuarine and marine bivalves is effected through a pelagic larval stage of short duration and is influenced by both passive (advection) and active (swimming) processes; however, there is considerable debate in the literature on the relative roles of these processes (see reviews by Mann 1986a and Stancyk \& Feller 1986). Larval dispersal as a completely

\footnotetext{
- Contribution no. 1613 from the School of Marine Science, Virginia Institute of Marine Science
}

passive process, in which larvae are merely drifters and encounter suitable conditions depending on water movements, has been supported by Korringa (1941, 1952), Manning \& Whaley (1954), Quayle (1969), Andrews (1979, 1983), Zinsmeister \& Emerson (1979), Boicourt (1982) and Seliger et al. (1982). Larval dispersal as an active and selective process in which larvae exercise some choice of their location in the water column (see Scheltema 1986) has been supported by Carriker (1951, 1961), Nelson (1953, 1955), Kunkle (1957) and Wood \& Hargis (1971). Wood \& Hargis (1971) suggested that different distributional patterns between veliger larvae of Crassostrea virginica Gmelin and inanimate coal particles were due to the fact that the latter followed the current patterns while the vel- 
iger larvae changed their vertical position in relation to salinity changes associated with the stage of the tide. Stancyk \& Feller (1986) have challenged this interpretation indicating that supporting experimental studies are lacking. Mann (1988) presented limited evidence of the ability of $C$. virginica to swim through salinity discontinuities representative of differences in surface and bottom salinities in the James River, Virginia (USA), but also gave field data illustrating passive transport of oyster larvae through frontal systems. In estuarine systems, at least, the debate over passive dispersal versus active depth regulation continues. Mann (1985) suggested that bivalve larval dispersal in a seasonally stratified coastal system could be the result of both active and passive processes. Larvae actively depth regulate in response to a summer thermocline but disperse passively, depending upon wind-driven currents, during the winter. Although both processes undoubtedly influence larval dispersal, Mann (1986b) stated that the point at which physical forces become sufficient to override any active component has not been adequately examined.

Estuaries exhibit salinity and temperature gradients both along their length and throughout their depth. Density differences in surface and bottom water contribute to net seaward flow at the surface and net landward flow at depth. Under such conditions minor vertical excursions associated with active depth regulation can contribute markedly to larval retention within the estuarine system. Field studies generally indicate that larvae are unevenly distributed throughout estuaries, showing ontogenetic differences in abundance when coupled to tides, current velocities, frontal systems and different locations within estuaries (Pritchard 1952, Nelson 1953, 1955, Manning \& Whaley 1954, Kunkle 1957, Seliger et al. 1982, Mann 1988). Laboratory experiments to examine the influence of oriented environmental stimuli, as encountered in estuaries, on larval behaviour have usually been designed to test a variety of intensities of stimulus applied sequentially rather than a gradient of stimulus. Only Harder (1968), Cragg \& Gruffydd (1975), Cragg (1980), Mann \& Wolf (1983) and Mann (1988) have examined bivalve larval behaviour under environmental gradients. The present study examined the swimming behaviour of larvae of 3 bivalve species from the family Mactridae in response to different salinities and to intense salinity discontinuities. These species, Spisula solidissima (Dillwyn 1817), Mulinia lateralis (Say 1822) and Rangia cuneata (Gray 1831), have pelagic planktotrophic larval stages that usually spend from 7 to $22 \mathrm{~d}$ in the plankton. As adult forms they occur naturally along a salinity gradient from coastal oceanic to brackish salinity regimes and therefore present an attractive group of species for both interspecific and intraspecific comparison of the influence of salinity on larval behaviour and adult distribution.

Spisula solidissima is considered a marine stenohaline species, predominantly found in oceanic waters where the salinity fluctuates between 28 and $34 \%$ (Gainey \& Greenburg 1977, Franz \& Merrill 1980, Theroux \& Wigley 1983); Mulinia lateralis, an euryhaline species, occurs in estuaries where the salinity varies from 18 to $30 \%$ (Lippson \& Lippson 1984); and Rangia cuneata, an oligohaline species, inhabits brackish waters with salinities ranging between 5 and $15 \%$ (Cain 1975, LaSalle \& de la Cruz 1985). The specific objectives of the study were to determine, using laboratory systems, whether vertical distribution, swimming and sinking velocities in these bivalve larvae differ ontogenetically, whether an intense salinity discontinuity modifies the vertical distribution of these bivalve larvae in a water column, and whether vertical velocities in these bivalve larvae are independent of salinity.

\section{MATERIALS AND METHODS}

Larval culture. Spisula solidissima adults were obtained from the American Original Clam Company, at Willis Wharf, Virginia, in April 1987. Mulinia lateralis adults were obtained from a stock maintained at the Virginia Institute of Marine Science (VIMS) Eastern Shore Laboratory, Wachapreague, Virginia, in April 1987. Rangia cuneata adults were collected from the Rappahanock River, Virginia, in September 1986 and from June to August 1987. After collection adult bivalves were scrubbed and rinsed with fresh water to remove epifauna from the shell, and maintained in filtered water at ambient temperature and at the salinity of the natural habitat during the spawning season of each of the species studied; i. e. $30 \%$ for S. solidissima, $25 \%$ for M. lateralis and $10 \%$ for $R$. cuneata. Gentle aeration was provided during the brief maintenance period prior to induced spawning to the adults. Water for adult maintenance, larval cultures and experiments came from the Wachapreague area, where the summer water salinity is usually over $28 \%$. Appropriate salinities were obtained by dilution of salt water with fresh water.

Larvae of each species were cultured following the procedures modified from Culliney et al. (1975), Castagna \& Kraeuter (1981) and Chanley (1981). Adults were induced to spawn by thermal stimulation (Kennedy et al. 1974, Goldberg 1980, Wright et al. 1983). Water temperature was raised to $24{ }^{\circ} \mathrm{C}$ for Spisula solidissima, to $28^{\circ} \mathrm{C}$ for Mulinia lateralis and to $32^{\circ} \mathrm{C}$ for Rangia cuneata. As soon as spawning began each female was transferred to an individual container filled with water of similar temperature and salinity. Males 
were pooled in a single container. Eggs were separated, several drops of $53 \mu \mathrm{m}$ filtered sperm suspension were added and the eggs left overnight to allow fertilization. After at least $24 \mathrm{~h}$, zygotes were siphoned out of the container onto a $20 \mu \mathrm{m}$ sieve, rinsed, and transferred to 31 glass bottles. Filtered water $(1 \mu \mathrm{m})$ was added to yield a final zygote concentration not exceeding $200001^{-1}$. When the number of zygotes produced by a female was insufficient $(<100000)$, zygotes of up to 5 females were pooled.

Cultures of Spisula solidissima and Mulinia lateralis larvae were maintained at a constant temperature of $23^{\circ} \mathrm{C}$; Rangia cuneata larvae were cultured at $25^{\circ} \mathrm{C}$. Salinity was maintained as for adults. All cultures were maintained under the prevailing day-night light cycle. Larvae were transferred to clean water every other day and fed immediately after each water change with ca 50 cells $\mu 1^{-1}$ unicellular algae [Pavlova (Monochrysis) lutheri Droop, Isochrysis galbana Parke and Isochrysis galbana (T-Iso) cultured by the procedure of Dupuy et al. (1977) and Guillard (1983)].

Response of larvae to salinity discontinuities. The experimental apparatus for examining larval responses in a salinity discontinuity is illustrated in Fig. 1. The travelling microscope allows observation and enumeration of larvae throughout the water column, including the vicinity of the salinity discontinuity, and estimation of vertical movement per unit time. In this study the following definitions were applied: upward swimming rate is the vertical distance toward the surface travelled by a larva in a unit time; downward swimming rate is the vertical distance travelled downwards by a larva in a unit time while actively swimming using the velum; and, sinking rate is the downward rate resulting from passive sinking with the velum retracted. These definitions should not be confused with absolute velocity described during the characteristic helical swimming pattern of a bivalve veliger (see Cragg \& Gruffydd 1975, Mann \& Wolf 1983).

Selection of an appropriate sized experimental chamber required consideration of the pattern of larval swimming, wall effects and the limitation of the optical device used in observation (see discussions in Winet 1973, Cragg 1980, Vogel 1981, Chia et al. 1984, and Mann 1988). Preliminary experiments were carried out to select the optimal chamber diameter for minimizing wall effects within optical constraints. Observation of larval motion in chambers of 2.0 and $0.6 \mathrm{~cm}$ internal diameter revealed that it was impossible to meet all of the optical requirements described earlier with the $2.0 \mathrm{~cm}$ chamber. Clear glass chambers, $30 \mathrm{~cm}$ long and of $0.6 \mathrm{~cm}$ internal diameter, were used to perform the experiments. This chamber height provides a reasonable vertical distance for larvae to swim, and permits complete coverage in the horizontal plane with the microscope. When only those larvae swimming or sinking near the central portion of the chamber were timed, no negative chamber effect was observed on the larval behaviour.

Salinity discontinuities were formed by careful loading of the experimental chamber with water of differing salinities. Preliminary experiments were performed to determine the feasibility of producing sharp and lasting salinity discontinuities in narrow chambers $10.6 \mathrm{~cm}$ diameter). Several experimental chambers were halffilled with high salinity water (e.g. $30 \%$ ) previously stained with neutral red. Then, clear and lower salinity water (e. g. 25,20 or $15 \%$ ) was very gently added to the top of the chambers. Chambers were observed every $24 \mathrm{~h}$ for $5 \mathrm{~d}$. A sharp, stable discontinuity could be produced even when the salinity between 2 layers differed by only $5 \%$ and could be maintained for at least $72 \mathrm{~h}$. Even though a sharp discontinuity of about $1 \mathrm{~mm}$ high could be easily produced, a $10 \mathrm{~mm}$ high
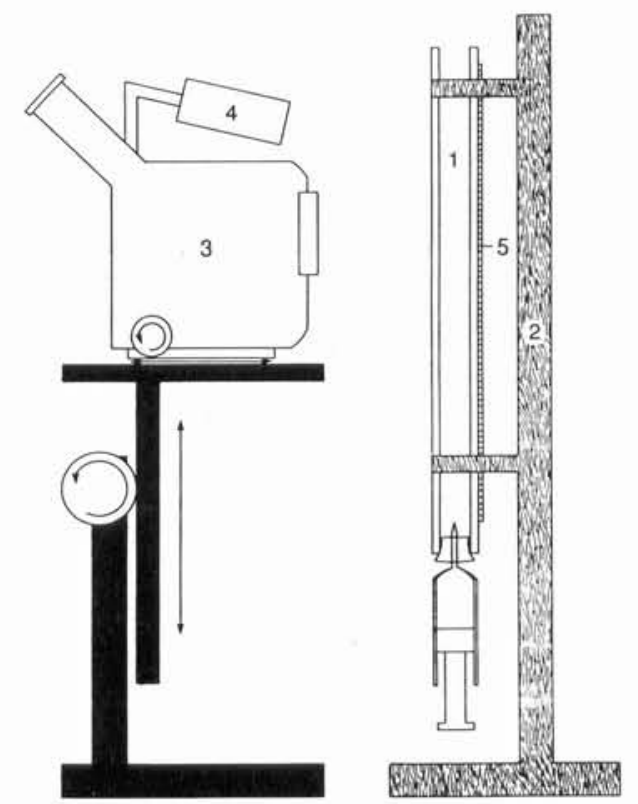

Fig. 1. Apparatus (not to scale) for examining bivalve larval responses to a salinity discontinuity. Larvae were maintained in a glass chamber (1), $30 \mathrm{~cm}$ high, $0.6 \mathrm{~cm}$ internal diameter. Access to the experimental chamber was from the open top and from the bottom through a syringe inserted into a rubber stopper fitted into the bottom end of the chamber. A wooden rack (2) was used to hold the chambers vertically. Larvae were observed through a dissecting stereomicroscope (3) fitted on a rack system that allows vertical and horizontal displacement. A lamp (4) installed on the top of the travelling microscope facilitated observation of the larvae. Optimum depth of field was obtained by adjusting the horizontal position and the zoom magnification of the microscope. The vertical distance travelled by the larvae was measured on a piece of graph paper, $25 \mathrm{~cm}$ high, $0.5 \mathrm{~cm}$ wide, ruled in $\mathrm{mm}$ (5), attached to the outside of the chamber 
discontinuity zone was established as the boundary between 2 water layers in experimental trials in order to reduce chances of error in the demarcation of the interface, which would affect interpretation of the results. The discontinuity zone was established by measuring $5 \mathrm{~mm}$ upwards and downwards from an initial boundary mark traced immediately after the high salinity water was added into the chamber.

At least $2 \mathrm{~h}$ prior to each experiment, larvae were siphoned from the culture jar and size-selected using nylon (Nitex) screens of different mesh sizes. Larvae of approximately the same size, retained on the same screen, were used in the experiments. Two methods were used to transfer the larvae into the experimental chambers while maintaining integrity of the salinity discontinuity. In the first method, $1 \mathrm{ml}$ of high salinity water was injected into the bottom of the chamber with a syringe. Approximately $2 \mathrm{ml}$ of the same high salinity water, containing larvae, was added from above followed by a further $1 \mathrm{ml}$ of the same salinity water. The inside chamber wall was dried to remove residual water left on the chamber wall during larval introduction. A horizontal line was traced on the outside of the chamber to demarcate the upper boundary of the high salinity water. Finally, an equal volume of lower salinity water was carefully added from above until the chamber was full. In the second method, the chamber was filled from below with $3.9 \mathrm{ml}$ of high salinity water and the boundary was marked as described earlier. Then, $1 \mathrm{ml}$ of low salinity water was carefully added from above, followed immediately by more water of the same salinity containing the larvae. Low salinity water was added until the chamber was completely filled. When full, each test chamber contained $7.8 \mathrm{ml}$ of water.

Experiments were conducted after an acclimation period of $30 \mathrm{~min}$ to avoid stress associated with manipulation. Illumination was maintained constant - dim room lighting with no external light - throughout all experiments. Room temperature was controlled at equal to culture temperature for species under investigation. Upon completion of the experiment the chamber was drained and larvae collected in individual, screw-top, $20 \mathrm{ml}$ vials and fixed with $4 \%$ buffered formalin. After $48 \mathrm{~h}$, this was replaced by $95 \%$ ethanol for preservation and larval storage. Shell length (maximum anterior-posterior dimension) of 25 preserved larvae from each replicate, for each larval stage, was measured with an ocular micrometer fitted to a light microscope at $100 \times$ magnification. Six replicate groups were used to perform experiments with Spisula solidissima and Mulinia lateralis and 5 with Rangia cuneata. In experiments using S. solidissima, each group originated from the ova of a different female and pooled sperm of several males; in those with $M$. lateralis and $R$. cuneata, each group originated from the mass spawn of separate groups of pooled females and pooled sperm of several males.

Larval distribution was examined with each larval stage in several salinity discontinuities and in a homogeneous water column (control) with the same salinity value as the water in which the larvae were cultured. Each stage for each species was examined separately; however, replicate groups within one species and one stage were examined simultaneously for their response when exposed to salinity discontinuities of different magnitude. The number of chambers functioning simultaneously for a species with 6 replicates and 3 salinity regimes was $19(6 \times 3$ plus 1 control). Magnitudes of salinity discontinuities were $5 \%$ (25/30), $10 \%$ (20/30) and $15 \%$ (15/30) for Spisula solidissima, $5 \%_{0}(25 / 30$ and $20 / 25)$ and $10 \%(15 / 25)$ for Mulinia lateralis, and 5\% (5/10 and 10/15) and $10 \%$ (10/20) for Rangia cuneata. In reality bivalve larvae do not encounter such high salinity discontinuities. The rationale for selection of these values was to include extremes of the range of tolerance of each species (Chanley 1965, Calabrese 1969, Cain 1973, Castagna \& Chanley 1973, Kennedy et al. 1974, Roosenburg et al. 1984) that could probably be encountered by larvae during their dispersal. The design assumes that if larval distribution was not affected by these extreme discontinuity values, then lower magnitudes or gradients as encountered in the field would make little or no difference to larval swimming behaviour.

The number of larvae used per experimental trial varied from 41 to 260 . The order in which salinity regimes and replicates were examined was randomized. The control was not replicated. Larval concentration in experiments was the most difficult factor to control. Since successive dilutions of larvae prior to experiments could cause some stress in their behaviour, a visual estimate of the number of larvae was the only alternative to minimise manipulation. In retrospect, a limit of 100 larvae is recommended for studies using chambers of a size similar to those used in this study.

Determination of swimming rate. Experiments were performed to determine whether ontogenetic stages displayed differences in vertical distribution, swimming and sinking rates. Three larval stages were examined: straight-hinge veliger, umbo veliger and pediveliger. Larval growth rate differed among the species. Each larval stage was correlated to the larval size, which was determined by measuring the anteriorposterior shell length of 25 larvae of each replicate used in the experiments.

Swimming rates for each larval stage subjected to different salinities were determined as follows. Larvae were maintained at the selected uniform salinity (not a 
salinity gradient as described previously) for $1 \mathrm{~h}$ before the upward rate was measured. A piece of graph paper, marked in millimeter increments, was attached to the rear wall of the test chamber and the time required to travel a unit distance was measured directly while making continuous observations using the traveling microscope. Upward swimming rates were recorded for a total of 30 larvae in each stage at each salinity. Larvae originated from two of the replicate cultures of each species. Observations of replicates were made simultaneously in adjacent chambers. Downward swimming and narcotized sinking rates of 35 to 50 larvae were recorded in a similar manner to determine whether these values change throughout the larval development.

Data were examined prior to testing specific hypotheses, to evaluate their compliance with assumptions of normality and homoscedasticity. Normality of the data was determined graphically with a stem and leaf test. Homogeneity of variances was tested with a Cochrans $\mathrm{C}$ test and a Bartlett-Box $\mathrm{F}$ test and judged significant at the 0.05 level. Within data sets describing upward and downward swimming, a consistent homogeneity of variance was not observed. The data were logarithmically $(\mathrm{ln})$ transformed and the test was repeated. Within each species the possibility of salinity-stage interactions was examined by a 2 -way analysis of variance on the transformed data. Hypotheses comparing means of a single dependent variable of 2 independent samples were tested with a t-test when variances of untransformed data were homogeneous or were made homogeneous by transformation, or a Mann-Whitney $U$ test when variances were heterogeneous despite transformation (Dowdy \& Wearden 1983, Zar 1984). Hypotheses comparing means of a single dependent variable of more than 2 independent samples were examined with 1-way ANOVA test for significance and subsequently by a multiple comparison Scheffe test, or a Kruskal-Wallis U test (nonparametric ANOVA) followed by a multiple comparison test. Multiple factor interactions were analyzed by a hierarchical log-linear $\mathrm{G}$ test (likelihood-ratio chisquare) (Sokal \& Rohlf 1981, Norusis 1985). All tests were conducted on a PRIME computer, using an SPSSX statistical package system.

\section{RESULTS}

Larval development to metamorphosis of Spisula solidissima, Mulinia lateralis and Rangia cuneata required 24,19 and $12 \mathrm{~d}$ respectively under the described conditions. Mean shell lengths of straight-hinge, umbo and pediveliger stages of each species as tested were as follows: S. solidissima, 95.6, 147.7 and $196.1 \mu \mathrm{m} ; M$. lateralis, 88.9, 121.0 and $159.7 \mu \mathrm{m}$; and $R$. cuneata, $103.7,130.6$ and $168.5 \mu \mathrm{m}$. Mean values were obtained from measurements of 25 individual larvae from each of either 5 or 6 replicate cultures of each species.

Larvae of the 3 species swam clockwise when viewed from below, independent of the vertical direction. Larvae exhibited a helical path although variations were observed depending on the stage of development. Straight-hinge larvae swam upwards and downwards along the whole chamber. Umbo larvae exhibited wider helices and tended to remain in a narrower vertical band than younger larvae. Umbo larvae actively swam upwards and downwards and occasionally sank with their valves closed. Pediveliger larvae also tended to remain in a certain depth band but, unlike umbo larvae, their descent was generally by passive sinking rather than active downward swimming.

\section{Swimming and sinking rates}

The upward swimming rate, defined as net vertical movement per unit time, of straight-hinge larvae of Spisula solidissima ranged from 0.18 to $0.26 \mathrm{~mm} \mathrm{~s}^{-1}$; of umbo larvae from 0.22 to $0.49 \mathrm{~mm} \mathrm{~s}^{-1}$; and of pediveliger larvae from 0.30 to $0.40 \mathrm{~mm} \mathrm{~s}^{-1}$ (Table 1). Both salinity and developmental stage have a significant effect on swimming rate; further, there is a positive interaction between salinity and stage (Table 2). Significant increases in swimming rate are seen in straight-hinge larvae between 25 and $30 \%$ salinity (1way ANOVA, $\mathrm{F}=4.78, \mathrm{p}=0.012$ ), in umbo larvae between 20 and $25 \%$ salinity (1-way ANOVA, $\mathrm{F}=$ $19.82, \mathrm{p}<0.0005)$, and in pediveliger larvae between 25 to $30 \%$ salinity ( $t=1.53, p=0.257$ ). Downward swimming rate was examined only for straight-hinge and umbo larvae (Table 1). A significant salinity effect was observed with umbo stage larvae (1-way ANOVA, $\mathrm{F}=12.20, \mathrm{p}<0.0005)$. Two-way ANOVA (Table 2) indicates that stage of development also influences swimming rate, with larger larvae generally swimming faster, but that a significant interaction of salinity and stage was absent (Table 2).

Upward swimming rate ranged from 0.25 to $0.43 \mathrm{~mm}$ $\mathrm{s}^{-1}$ for Mulinia lateralis straight-hinge larvae, from 0.32 to $0.50 \mathrm{~mm} \mathrm{~s}^{-1}$ for umbo larvae and from 0.31 to $0.34 \mathrm{~mm} \mathrm{~s}^{-1}$ for pediveliger larvae (Table 1). Two-way ANOVA indicates that both salinity and stage of development had a significant effect on swimming, with a significant interaction (Table 2). Mean swimming rate of umbo larvae at $20 \%$ salinity and below was significantly lower than at 25 and $30 \%$ salinity (Mann Whitney U, p $=0.019$ ). No salinity effect was observed with the limited data set for pediveliger lar- 
Table 1. Spisula solidissima, Mulinia lateralis and Rangia cuneata. Upward and downward swimming rates (mean \pm SD in mm $\mathrm{s}^{-1}$ ) of larval stages at various salinities. $\mathrm{S}$ : straight-hinge stage; $\mathrm{U}$ : umbo stage; $\mathrm{P}$ : pediveliger stage. $\mathrm{N}=30$ in all cases except where value given in parentheses

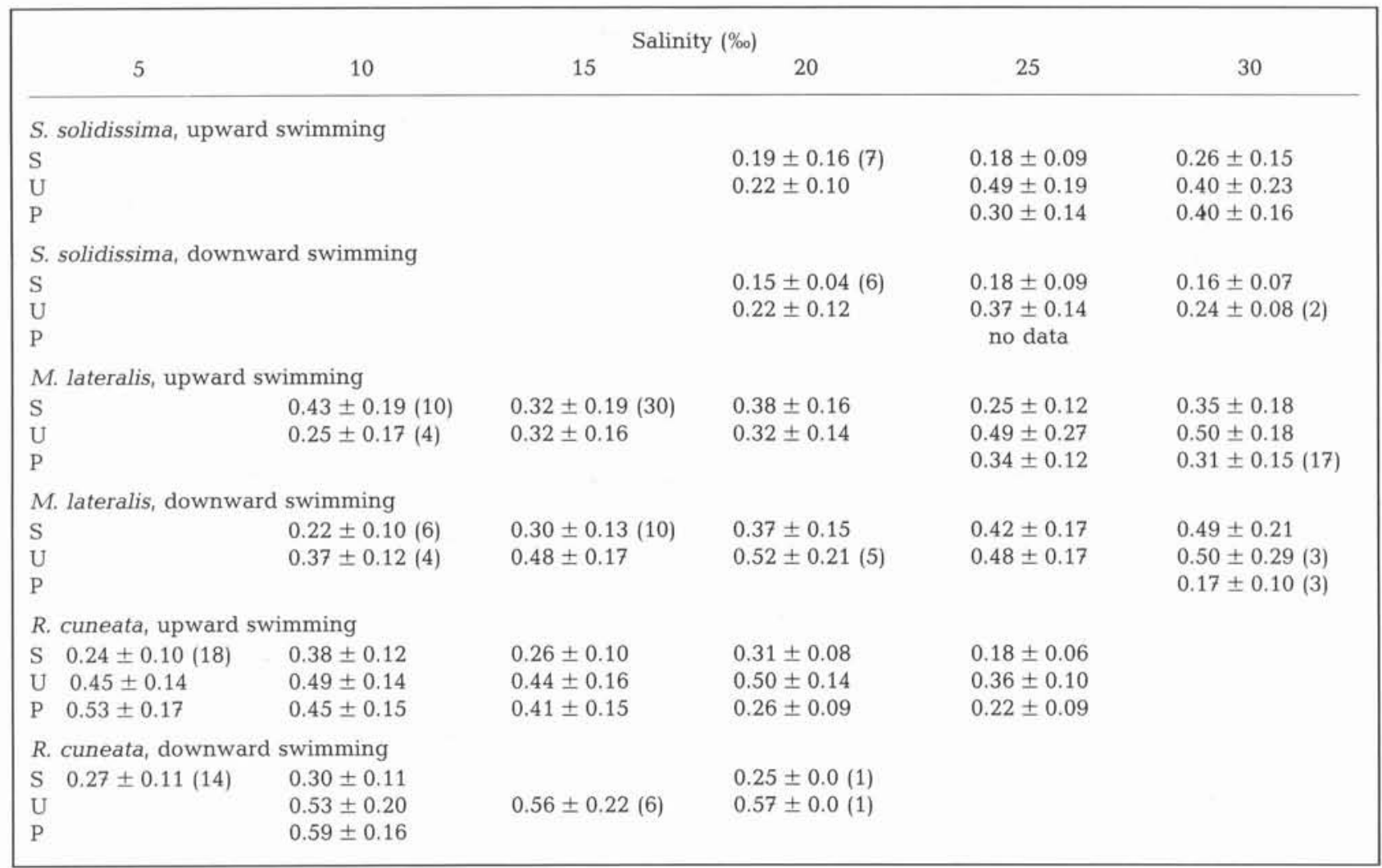

vae $(\mathrm{t}=2.14, \mathrm{p}=0.073)$. The majority of downward swimming rate data was recorded for the first 2 stages of development because only a few pediveliger larvae swam downwards; passive sinking was much more frequent. Salinity had a significant effect on downward swimming rate (Table 2). Mean values for straighthinge larvae demonstrated a notable and consistent increase with salinity (1-way ANOVA, $\mathrm{F}=4.805, \mathrm{p}=$ 0.001 ) but this was not evident in umbo larvae (1-way ANOVA, $\mathrm{F}=0.332, \mathrm{p}=0.855)$. The influence of stage of development on swimming rate is evident in comparisons of rates for straight-hinge versus umbo larvae (Tables 1 and 2) where the latter are generally higher. Upward swimming rate of Rangia cuneata straighthinge veliger larvae ranged from 0.18 to $0.38 \mathrm{~mm} \mathrm{~s}^{-1}$; of umbo larvae from 0.36 to $0.50 \mathrm{~mm} \mathrm{~s}^{-1}$; and of pediveliger larvae, from 0.22 to $0.53 \mathrm{~mm} \mathrm{~s}^{-1}$ (Table 1). Both salinity and stage had a significant effect on swimming rate (Table 2). There was a significant interaction of salinity and stage of development. Lowest values of upward swimming rate were consistently recorded at $25 \%$, the highest salinity tested, irrespective of stage (1-way ANOVA by stage; straight-hinge, $\mathrm{F}=21.20, \mathrm{p}<0.0005 ;$ umbo, $\mathrm{F}=5.06, \mathrm{p}=0.001$; pediveliger, $\mathrm{F}=33.98, \mathrm{p}<0.0005)$. At higher salinities umbo stage larvae exhibited higher mean rates than other stages; however, at lower salinities values for umbo and pediveliger stage larvae were generally comparable (Table 1). Data describing downward swimming rate in $R$. cuneata is more limited than that for the other species. Only stage had a significant effect on swimming rate (Table 2).

Sinking rate (Table 3 ) increased significantly with each larval stage in both Spisula solidissima and Mulinia lateralis. Rangia cuneata, by contrast, exhibited a different pattern: straight-hinge larvae sank at $2.31 \mathrm{~mm} \mathrm{~s}^{-1}$, umbo larvae sank at $1.36 \mathrm{~mm} \mathrm{~s}^{-1}$ and pediveliger larvae sank at $1.74 \mathrm{~mm} \mathrm{~s}^{-1}$. Differences in sinking rate among the 3 stages were significant.

\section{Response to salinity discontinuities}

It is important to remember that larvae were subjected to constant light and geotactic stimuli when examining the present observations of vertical distribution. Distribution in the control condition represents response to these stimuli and the experimental hand- 
Table 2. Results of 2-way analysis of variance of logarithmically (ln) transformed data describing upward and downward swimming rates of 3 stages of development of Spisula solidissima, Mulinia lateralis and Rangia cuneata at various salinities

\begin{tabular}{|c|c|c|c|c|}
\hline & SS & df & $\mathrm{F}$ & $\mathrm{p}$ \\
\hline \multicolumn{5}{|c|}{ S. solidissima, upward swimming } \\
\hline Salinity & 12.58 & 2 & 25.11 & $<0.0005$ \\
\hline Stage & 15.67 & 2 & 31.26 & $<0.0005$ \\
\hline Salinity $\times$ Stage & 4.97 & 3 & 6.61 & $<0.0005$ \\
\hline \multicolumn{5}{|c|}{ S. solidissima, downward swimming } \\
\hline Salinity & 2.40 & 2 & 4.98 & 0.008 \\
\hline Stage & 2.97 & 1 & 12.29 & 0.001 \\
\hline Salinity $\times$ Stage & 0.94 & 2 & 1.95 & 0.146 \\
\hline \multicolumn{5}{|c|}{ M. lateralis, upward swimming } \\
\hline Salinity & 4.88 & 4 & 5.31 & $<0.0005$ \\
\hline Stage & 4.19 & 2 & 9.10 & $<0.0005$ \\
\hline Salinity $\times$ Stage & 8.76 & 5 & 7.62 & $<0.0005$ \\
\hline \multicolumn{5}{|c|}{ M. lateralis, downward swimming } \\
\hline Salinity & 2.18 & 4 & 2.69 & 0.033 \\
\hline Stage & 2.02 & 1 & 9.98 & 0.002 \\
\hline Salinity $\times$ Stage & 1.06 & 4 & 1.31 & 0.270 \\
\hline \multicolumn{5}{|c|}{ R. cuneata, upward swimming } \\
\hline Salinity & 18.38 & 4 & 39.60 & $<0.0005$ \\
\hline Stage & 20.18 & 2 & 86.95 & $<0.0005$ \\
\hline Salinity $\times$ Stage & 10.88 & 8 & 11.72 & $<0.0005$ \\
\hline \multicolumn{5}{|c|}{ R. cuneata, downward swimming } \\
\hline Salinity & 0.13 & 3 & 0.25 & 0.863 \\
\hline Stage & 4.86 & 1 & 28.36 & $<0.0005$ \\
\hline Salinity $\times$ Stage & 0.03 & 1 & 0.18 & 0.669 \\
\hline
\end{tabular}

ling procedure. Distribution in the presence of a salinity discontinuity represents modification of the control condition by the discontinuity. The volume of the discontinuity, as demarcated, represents ca $3 \%$ of the total volume of the experimental chamber. Data have been expressed in Tables 4 to 6 as a percentage of the total number present in the chosen layer or discontinuity and total present (n) in the described experimental trial. Changes in distribution relative to the control are expressed as change in percentage distribution $(\mathrm{d} \%)$ to facilitate between treatment comparisons.

Spisula solidissima larvae displayed a distinctive non-homogeneous vertical distribution $(\mathrm{G}=12.151$, $\mathrm{df}=4, \mathrm{p}=0.0163)($ Table 4$)$. Vertical distribution did not differ among replicates within stage-salinity regime combinations. In the control condition $(30 / 30 \%$ salinity) larvae were more abundant in the upper layer than in the discontinuity or the lower layer; however, disproportionate concentration in the discontinuity suggests a possible handling stress modifying a weak negative geotaxis. In all 3 discontinuity regimes and in all larval stages a pronounced aggregation was seen in the discontinuity layer. With one exception - pediveligers in the $25 / 30 \%$ salinity regime - this was accompanied by a decreased presence in the overlying, less saline water. A general, smaller, but not exclusive, trend of movement into the discontinuity from the bottom high salinity layer was also observed. Although larvae of all stages would capably swim in the $25 \%$ salinity water there was clear avoidance of the 15 and $20 \%$ salinity water.

Mulinia lateralis larvae were not homogeneously distributed in the water column $(\mathrm{G}=35.779, \mathrm{df}=2, \mathrm{p}=$ 0.0001 ) (Table 5). Vertical distribution did not differ among replicates within stage-salinity regime combinations. In the control condition ( $25 / 25 \%$ salinity) straighthinge and umbo larvae exhibited strong negative geotaxis. Pediveliger larvae were positively geotactic. With an increase in salinity of the lower layer $(25 / 30 \%$ salinity) a notable aggregation in the discontinuty was observed in all stages; however, the source of the aggregation differed with stage when compared to the control distribution. At straight-hinge stage, larvae came mostly from the surface layer, at umbo, from above and below the discontinuity, and at the pediveliger stage predominantly from below. With decreasing overlying salinities a marked decrease in straight-hinge and umbo negative geotaxis and a marked increase in aggregation in the discontinuity was observed. Similar distributional changes, but of smaller magnitude, were observed in the pediveliger stage.

Rangia cuneata larvae were not homogeneously distributed along the water column $(\mathrm{G}=37.25, \mathrm{df}=2, \mathrm{p}=$ 0.0001) (Table 6). Vertical distribution did not differ among replicates within stage-salinity regime combinations. In the control regime $(10 / 10 \%$ salinity $)$ straight-hinge and umbo larvae exhibited negative

Table 3. Sinking rate (mean $\pm \mathrm{SD}$ in $\mathrm{mm} \mathrm{s}^{-1}$ ) of 3 larval stages of Spisula solidissima at $30 \%$, Mulinia lateralis at $25 \%$, and Rangia cuneata at $10 \%$ salinity respectively. Within species comparisons effected by a multiple comparison test and 1-way ANOVA or Kruskal-Wallis test (see 'Materials and methods'). $\mathrm{N}=50$ in all cases except ' when $\mathrm{N}=35$

\begin{tabular}{|lccccc|}
\hline Species & Straight-hinge & $\begin{array}{c}\text { Stage } \\
\text { Umbo }\end{array}$ & Pediveliger & Significance \\
\hline S. solidissima & $0.64 \pm 0.13$ & $1.33 \pm 0.30$ & $2.23 \pm 0.49^{*}$ & $\mathrm{~F}=275.9$ & $\mathrm{p}<0.001$ \\
M. lateralis & $0.67 \pm 0.09$ & $1.12 \pm 0.16$ & $1.30 \pm 0.24$ & $\chi^{2}=106.6$ & $\mathrm{p}<0.001$ \\
R. cuneata & $2.31 \pm 0.73$ & $1.36 \pm 0.31$ & $1.74 \pm 0.58$ & $\mathrm{~F}=35.09$ & $\mathrm{p}<0.001$ \\
\hline
\end{tabular}


Table 4. Spisula solidissima. Vertical distribution of larvae of 3 developmental stages, subjected to 4 salinity regimes. Each salinity layer and the discontinuity (Disc.) between them, in the vertical order in which they were positioned in the experiments, is indicated as Layer. Number (n) and percentage of larvae (\%) were obtained at the termination of the 30 min trials. All data are means of 6 replicates. d\% represents the change in distribution relative to the control condition of $30 / 30^{\circ}$ salinity. Larvae were initially placed in the $30 \%$ salinity layer. $30^{\circ}=30 \%$ salinity layer but initially without larvae

\begin{tabular}{|c|c|c|c|c|c|c|c|}
\hline \multirow[t]{2}{*}{$\begin{array}{l}\text { Salinity } \\
\text { regime }\end{array}$} & \multirow[t]{2}{*}{ Layer } & \multicolumn{2}{|c|}{$\begin{array}{l}\text { Str.-hinge } \\
\text { larvae }\end{array}$} & \multicolumn{2}{|c|}{$\begin{array}{l}\text { Umbo } \\
\text { larvae }\end{array}$} & \multicolumn{2}{|c|}{$\begin{array}{c}\text { Pediveliger } \\
\text { larvae }\end{array}$} \\
\hline & & $\%$ & $\mathrm{~d} \%$ & $\%$ & $d \%$ & $\%$ & $\mathrm{~d} \%$ \\
\hline \multirow[t]{2}{*}{$25 / 30$} & $\begin{array}{c}25 \\
\text { Disc. } \\
30\end{array}$ & $\begin{array}{l}19.1 \\
68.0 \\
12.9\end{array}$ & $\begin{array}{l}-21.9 \\
+35.9 \\
-13.2\end{array}$ & $\begin{array}{l}39.7 \\
45.7 \\
14.6\end{array}$ & $\begin{array}{c}-29.9 \\
+33.4 \\
-3.7\end{array}$ & $\begin{array}{r}23.1 \\
67.5 \\
9.4\end{array}$ & $\begin{array}{l}+2.9 \\
+18.8 \\
-21.7\end{array}$ \\
\hline & $\mathrm{n}$ & \multicolumn{2}{|c|}{155.4} & \multicolumn{2}{|c|}{59.5} & \multicolumn{2}{|c|}{78.2} \\
\hline \multirow[t]{2}{*}{$20 / 30$} & $\begin{array}{c}20 \\
\text { Disc. } \\
30\end{array}$ & $\begin{array}{r}1.3 \\
81.5 \\
17.2\end{array}$ & $\begin{array}{r}-40.5 \\
+49.4 \\
-\quad 8.9\end{array}$ & $\begin{array}{r}3.2 \\
83.7 \\
13.1\end{array}$ & $\begin{array}{l}-66.2 \\
+71.4 \\
-5.2\end{array}$ & $\begin{array}{r}0.9 \\
79.0 \\
20.1\end{array}$ & $\begin{array}{l}-19.3 \\
+30.3 \\
-11.0\end{array}$ \\
\hline & $\mathrm{n}$ & \multicolumn{2}{|c|}{260.2} & \multicolumn{2}{|c|}{126.7} & \multicolumn{2}{|c|}{73.1} \\
\hline \multirow[t]{2}{*}{$15 / 30$} & $\begin{array}{c}15 \\
\text { Disc. } \\
30\end{array}$ & $\begin{array}{r}0.1 \\
75.3 \\
24.6\end{array}$ & $\begin{array}{r}-41.7 \\
+50.7 \\
-\quad 1.5\end{array}$ & $\begin{array}{r}0.1 \\
89.2 \\
10.7\end{array}$ & $\begin{array}{r}-69.3 \\
+76.9 \\
+7.6\end{array}$ & $\begin{array}{r}0.0 \\
69.8 \\
30.2\end{array}$ & $\begin{array}{r}-20.2 \\
+21.1 \\
-0.9\end{array}$ \\
\hline & $\mathrm{n}$ & \multicolumn{2}{|c|}{171.8} & \multicolumn{2}{|c|}{179.3} & \multicolumn{2}{|c|}{59.6} \\
\hline \multirow[t]{2}{*}{$30 / 30^{\circ}$} & $\begin{array}{c}30^{\circ} \\
\text { Disc. } \\
30\end{array}$ & $\begin{array}{l}41.8 \\
32.1 \\
26.1\end{array}$ & & $\begin{array}{l}69.4 \\
12.3 \\
18.3\end{array}$ & & $\begin{array}{l}20.2 \\
48.7 \\
31.1\end{array}$ & \\
\hline & $\mathrm{n}$ & \multicolumn{2}{|c|}{72.5} & \multicolumn{2}{|c|}{54.5} & \multicolumn{2}{|c|}{41.1} \\
\hline
\end{tabular}

Table 5. Mulinia lateralis. Vertical distribution of larvae of 3 developmental stages, subjected to 5 salinity regimes. Legend as in Table $4.25 / 25^{\circ}$ is the control condition. Larvae were initially placed in the $25 \%$ salinity layer. $25^{\circ}=25 \%$ salinity layer but initially without larvae

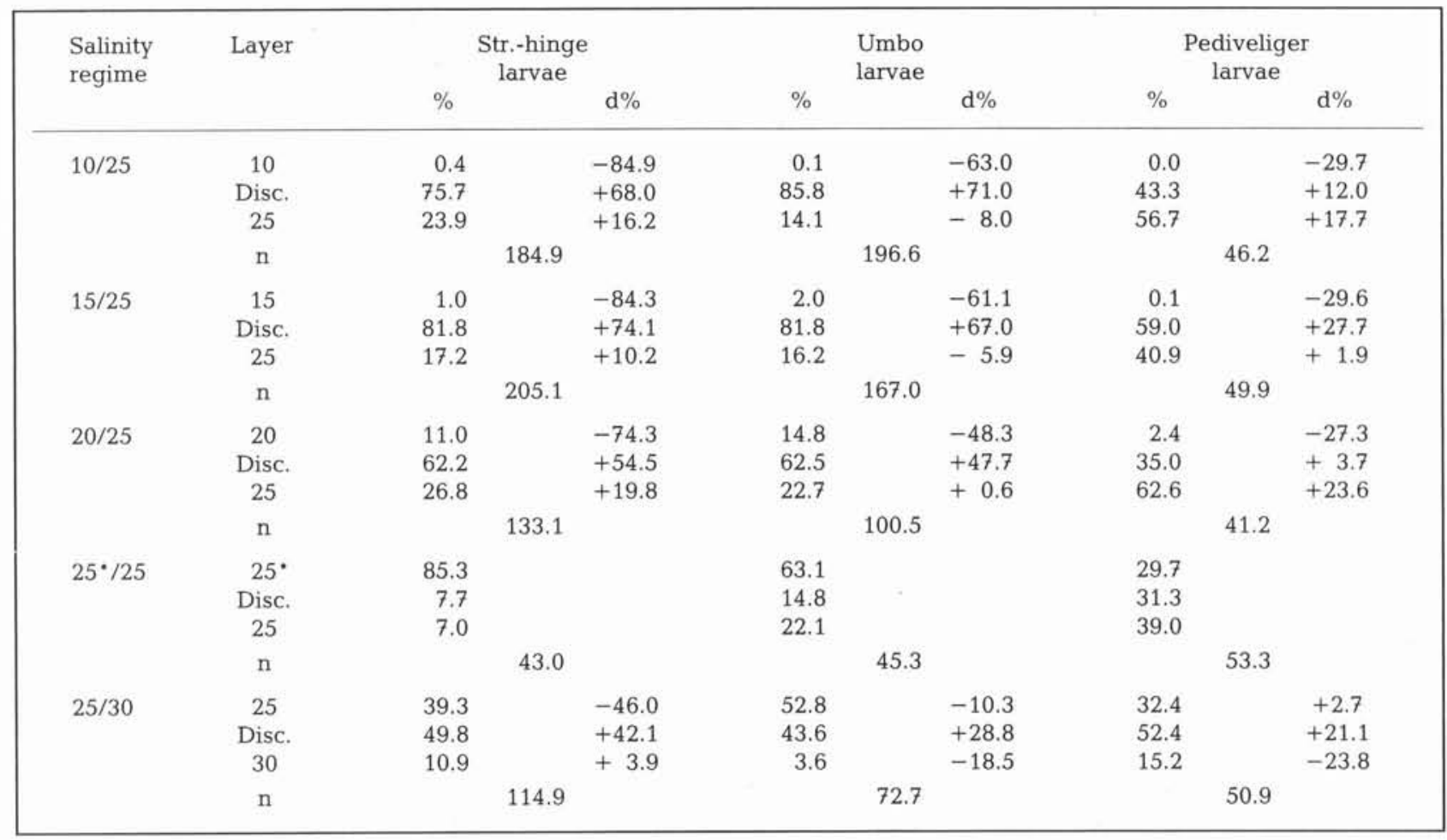


Table 6. Rangia cuneata. Vertical distribution of larvae of 3 developmental stages, subjected to 5 salinity regimes. Legend as in Table 4 . Larvae were initially placed in the $10 \%$ salinity layer. $10^{*}=10 \%$ salinity layer but initially without larvae

\begin{tabular}{|c|c|c|c|c|c|c|c|}
\hline \multirow[t]{2}{*}{$\begin{array}{l}\text { Salinity } \\
\text { regime }\end{array}$} & \multirow[t]{2}{*}{ Layer } & \multicolumn{2}{|c|}{$\begin{array}{l}\text { Str.-hinge } \\
\text { larvae }\end{array}$} & \multicolumn{2}{|c|}{$\begin{array}{l}\text { Umbo } \\
\text { larvae }\end{array}$} & \multicolumn{2}{|c|}{$\begin{array}{c}\text { Pediveliger } \\
\text { larvae }\end{array}$} \\
\hline & & $\%$ & $d \%$ & $\%$ & $\mathrm{~d} \%$ & $\%$ & $\mathrm{~d} \%$ \\
\hline \multirow[t]{2}{*}{$05 / 10$} & $\begin{array}{c}05 \\
\text { Disc. } \\
10\end{array}$ & $\begin{array}{r}4.1 \\
84.1 \\
11.8\end{array}$ & $\begin{array}{l}-37.2 \\
+49.3 \\
-12.1\end{array}$ & $\begin{array}{r}3.9 \\
82.5 \\
13.6\end{array}$ & $\begin{array}{l}-42.0 \\
+45.7 \\
-3.7\end{array}$ & $\begin{array}{r}5.6 \\
87.0 \\
7.4\end{array}$ & $\begin{array}{l}-20.2 \\
+50.4 \\
-30.2\end{array}$ \\
\hline & $\mathrm{n}$ & \multicolumn{2}{|c|}{165.7} & \multicolumn{2}{|c|}{140,4} & \multicolumn{2}{|c|}{194.7} \\
\hline \multirow[t]{2}{*}{$10-10^{*}$} & $\begin{array}{c}10 \\
\text { Disc. } \\
10^{\circ}\end{array}$ & $\begin{array}{l}41.3 \\
34.8 \\
23.9\end{array}$ & & $\begin{array}{l}45.9 \\
36.8 \\
17.3\end{array}$ & & $\begin{array}{l}25.8 \\
36.6 \\
37.6\end{array}$ & \\
\hline & $\mathrm{n}$ & \multicolumn{2}{|c|}{57.6} & \multicolumn{2}{|c|}{54.4} & \multicolumn{2}{|c|}{63.6} \\
\hline \multirow[t]{2}{*}{$10 / 15$} & $\begin{array}{c}10 \\
\text { Disc. } \\
15\end{array}$ & $\begin{array}{r}40.7 \\
58.0 \\
1.3\end{array}$ & $\begin{array}{l}-0.6 \\
+23.2 \\
-22.6\end{array}$ & $\begin{array}{r}48.2 \\
51.4 \\
0.4\end{array}$ & $\begin{array}{l}+2.3 \\
+14.6 \\
-16.9\end{array}$ & $\begin{array}{r}53.2 \\
45.4 \\
1.4\end{array}$ & $\begin{array}{l}+27.4 \\
+\quad 8.8 \\
-36.2\end{array}$ \\
\hline & $\mathrm{n}$ & \multicolumn{2}{|c|}{83.6} & \multicolumn{2}{|c|}{66.1} & \multicolumn{2}{|c|}{79.4} \\
\hline \multirow[t]{2}{*}{$10 / 20$} & $\begin{array}{c}10 \\
\text { Disc. } \\
20\end{array}$ & $\begin{array}{r}36.8 \\
60.9 \\
2.3\end{array}$ & $\begin{array}{l}-45.0 \\
+26.1 \\
-21.6\end{array}$ & $\begin{array}{r}44.7 \\
54.3 \\
1.0\end{array}$ & $\begin{array}{l}-1.2 \\
+17.5 \\
-16.3\end{array}$ & $\begin{array}{r}43.5 \\
53.4 \\
3.1\end{array}$ & $\begin{array}{l}+17.7 \\
+16.8 \\
-34.5\end{array}$ \\
\hline & $\mathrm{n}$ & \multicolumn{2}{|c|}{106.0} & \multicolumn{2}{|c|}{77.3} & \multicolumn{2}{|c|}{106.2} \\
\hline \multirow[t]{2}{*}{$10 / 25$} & $\begin{array}{c}10 \\
\text { Disc. } \\
25\end{array}$ & $\begin{array}{r}28.1 \\
66.0 \\
5.9\end{array}$ & $\begin{array}{r}-13.2 \\
+31.2 \\
-18.0\end{array}$ & $\begin{array}{r}24.8 \\
71.6 \\
3.6\end{array}$ & $\begin{array}{l}-21.1 \\
+34.8 \\
-13.7\end{array}$ & $\begin{array}{r}40.6 \\
52.8 \\
6.6\end{array}$ & $\begin{array}{l}+14.8 \\
+16.2 \\
-31.0\end{array}$ \\
\hline & $\mathrm{n}$ & \multicolumn{2}{|c|}{121.0} & \multicolumn{2}{|c|}{126.6} & \multicolumn{2}{|c|}{95.8} \\
\hline
\end{tabular}

geotaxis; however, in all instances a disproportionately large percentage of larvae occupied the discontinuity layer. Irrespective of the accompanying salinity, whether lower or higher, both straight-hinge and umbo larvae consistently exhibited aggregation in the discontinuity layer, especially so in the presence of $5 \%$ salinity water, when compared to the control condition. Larvae of all stages clearly avoided all salinities other than $10 \%$ and the adjacent discontinuity layers. On no occasion did the percentage of total larvae in $5,10,20$ or $25 \%$ salinity water exceed $6.6 \%$ of the total present in the experimental regime. Pediveliger larvae displayed aggregation in both the discontinuity and the overlying $10 \%$ salinity water in the presence of a high salinity bottom layer; however, in the $5 / 10 \%$ salinity regime they avoided both 5 and $10 \%$ water and exhibited extreme aggregation in the discontinuity.

\section{DISCUSSION}

The observed increase in mean upward swimming rate to a maximum by umbo larvae and subsequent decrease by pediveliger stage is consistent with the generalised ontogenetic changes in larval weight, specific gravity and velar morphology as described by
Chia et al. (1984). The velum is developed to its maximum extent at the end of the umbo stage; during the pediveliger stage larval mass and specific gravity increase until the velum is unable to counteract the larval mass and efficiently propel the larva. Consequently, larvae tend to concentrate near the bottom of the experimental chamber where they begin to search and test the substrate for settlement.

The range of mean upward swimming rate of larvae of the 3 species was between 0.18 and $0.53 \mathrm{~mm} \mathrm{~s}^{-1}$; this range embraces velocity values reported for Crassostrea virginica (Hidu \& Haskin 1978), Pecten maximus L. (Cragg 1980) and Arctica islandica L. (Mann \& Wolf 1983). Comparisons of swimming rates from this study with previously reported values for larvae of other bivalve species are difficult because, as Mileikovsky (1973) noted, neither the type of velocity (absolute, sensu Cragg \& Gruffydd (1975), or vertical, as used in this study), swimming direction (upward or downward), nor environmental conditions (e. g. temperature and salinity) in which these measurements were obtained have generally been reported. Lack of uniformity in both experimental methods and data reporting are a potential source of confusion and error. For example the reviews of Mileikovsky (1973) and Chia et al. (1984) report differently the original velocity 
data for Mercenaria mercenaria L., C. virginica and Lyrodus pedicellatus DeQuatrefages (the latter from Isham \& Tierney (1953) in which they identified the species as Teredo pedicellata). In the present study, salinity and stage of development exhibit influence on upward swimming rate, both in isolation and interactively. Such a consistent response of swimming rate to salinity and stage of development supports the suggestion that larvae are sensitive to environmental salinity gradients encountered during development and respond to them by regulated swimming activity, a suggestion further supported by the behavioural studies effected in salinity discontinuities.

Downward swimming rate was not measured at all the stage and salinity combinations reported for upward swimming; however, values obtained were of comparable magnitude to those for upward swimming rate. Although stage (for all species) and salinity (for Spisula solidissima and Mulinia lateralis only, data for Rangia cuneata being more limited) individually exhibit statistically significant influences on downward swimming, an interaction is consistently lacking (Table 2). Upward swimming is affected by state of velar development, as mentioned earlier, while velar activity may be modified by ambient salinity. Both stage of development and salinity clearly interact in this scenario. Changes in density and viscosity of seawater over the salinity range examined here are very small and cannot be reasonably invoked as causative of the observed changes. Downward swimming with the velum extended in the present context is essentially passive sinking modified by limited velar activity. The salinity-independent passive sinking component is dictated by larval size and specific gravity as discussed in more detail below. The salinity-dependent withinstage effect reflects modification of limited velar activity by salinity.

Passive larval sinking rate $\left(0.64\right.$ to $2.31 \mathrm{~mm} \mathrm{~s}^{-1}$ ) was always higher than active swimming rate in the 3 species. A strict comparison between present results on larval sinking and other literature values can only be made between Spisula solidissima and the extensive data for Crassostrea virginica larvae presented by Hidu \& Haskin (1978). In these species, sinking rate was recorded under similar temperatures $\left(23\right.$ and $25^{\circ} \mathrm{C}$ respectively) and salinity (25\%) conditions. Although $S$. solidissima straight-hinge larvae were larger $(95.8 \mu \mathrm{m})$ than comparable $C$. virginica $(75.0 \mu \mathrm{m})$, mean sinking rate of the former was lower $(0.60$ versus $\left.1.67 \mathrm{~mm} \mathrm{~s}^{-1}\right) . \quad S$. solidissima pediveliger larvae $(195.3 \mu \mathrm{m})$ sank considerably slower $\left(2.20 \mathrm{~mm} \mathrm{~s}^{-1}\right.$ than $300 \mu \mathrm{m}$ pediveliger larvae of both C. virginica $\left(8.30 \mathrm{~mm} \mathrm{~s}^{-1}\right)$ and Ostrea edulis $\left(6.00 \mathrm{~mm} \mathrm{~s}^{-1}\right)$ (Walne 1965); however, sinking rate for $O$. edulis was calculated for larvae swimming at $21^{\circ} \mathrm{C}$ and ca 31 to $32 \%$.
Walne (1965) presents the hypothesis that larval sinking depends on larval size. The data of Hidu \& Haskin (1978) suggest a linear relationship between sinking rate and larval length while Chia et al. (1984) suggest that sinking is proportional to the square of body size. Linear regression of sinking rates against both length and length squared for cumulative data of Walne (1965), Hidu \& Haskin (1978) and the present study indicate comparable correlation coefficients for both analyses $\left(\mathrm{S}=0.031 \mathrm{~L}-1.594, \mathrm{r}=0.84\right.$, and $\mathrm{S}=0.083\left[\mathrm{~L}^{2}\right.$ $\times 10^{-3}$ ) $+0.731, \mathrm{r}=0.852$ where $\mathrm{S}$ is sinking rate in $\mathrm{mm} \mathrm{s}^{-1}$ and $\mathrm{L}$ is larval length in $\mu \mathrm{m}$.

Reported values of larval specific gravity are rare. Gallager (1985) found a value of $1.192 \mathrm{~g} \mathrm{~cm}^{-1}$ for Bankia gouldi Bartsch pediveligers. No major differences were observed in the sinking rate among umbo larvae of the 3 species examined in the present study. Possible explanations for the observed high sinking rate of Rangia cuneata straight-hinge larvae compared to those of Spisula solidissima and Mulinia lateralis might include species-specific ontogenetic differences in larval lipid content (see Vogel 1981, Gallager et al. 1986, Lucas et al. 1986 for a discussion of the role of lipid in buoyancy of larvae) and shell thickness. Although not quantitatively determined, it is reasonable to predict a thicker shell in $R$. cuneata larvae, even at the straight-hinge stage, in comparison to the other 2 species. Since $R$. cuneata larvae swim in brackish water, a thicker shell could be a protective mechanism against dissolution at low $\mathrm{pH}$ (brackish waters may be less well buffered than the more saline waters of estuaries). The greater sinking rate of $S$. solidissima pediveliger larvae compared to the other 2 species can be explained simply by differences in size.

Effects of environmental variables on mactrid larval tolerances and growth rate have been studied extensively (Cain 1972, 1973 for Rangia cuneata, Kennedy et al. 1974 for Mulinia lateralis, Roosenburg et al. 1984 for Spisula solidissima). Specific studies of behavioural responses to salinity discontinuities have not previously been reported for mactrid larvae. All 3 species examined here exhibited strong aggregation responses to the presence of discontinuities. In addition, individual species exhibited salinity preferences by their relative abundance in water above and below the discontinuities. S. solidissma preferred $30 \%$ salinity, $M$. lateralis preference changed from $30 \%$ salinity at straight-hinge to $25 \%$ salinity at pediveliger, while $R$. cuneata clearly avoided all but $10 \%$ salinity water. Only Harder (1968) and Mann (1988) report on responses of other bivalve larvae to laboratory-generated salinity discontinuities. Harder (1968) subjected Teredo diegensis larvae to salinity discontinuities ranging from 1.05 to $17.24 \%$ (a constant lower layer of $33.75 \%$ salinity; upper layer variable). Larvae distributed ran- 
domly when the magnitude of the discontinuity was $3.65 \%$ salinity ( 30.1 over 33.75 ) suggesting that the difference was too small to have any marked effect on phototactic and geotactic behaviour. When the difference was increased to $5.19 \%$ salinity ( 28.56 over $33.75 \%$ ) larvae accumulated immediately above the discontinuity illustrating an enhancement of negative geotactic behaviour and clear preference for the lower salinity. A further increase in the discontinuity to $17.24 \%$ salinity ( 16.51 over $33.75 \%$ ) resulted in the return of the larvae to the lower, high salinity layer suggesting that the lower salinity was below the optimum for the species.

Mann (1988) described swimming of Crassostrea virginica larvae, previously acclimated to $22 \%$ salinity, in experimental water columns where water at $19 \%$ was layered over water at $22 \%$ at a uniform temperature. Larvae exhibited no hesitation in swimming through the discontinuity. Lance (1962) and Harder (1968) stated that most zooplankters could perceive and be affected by a salinity discontinuity. Unfortunately, Harder, in his account of Teredo diegensis larvae, gave no details on the acclimation period prior to the data gathering, the salinity to which the larvae were originally exposed or possible ontogenetic changes in larval responses. Harder suggested that density rather than salinity was the property controlling distribution of organisms in his experiments and that density discontinuities might be preferred sites for some zooplankters. The relative influences are, however, difficult to separate in his experimental regime. They are not separable in the experiments of Mann (1988). In an ecological context such distinction may be minor in that density changes will always be accompanied by a change in salinity, temperature or both. Salinity and temperature gradients or discontinuities in experimental systems, and thermoclines and gradients in possible food concentration in natural systems have been shown to influence distribution of bivalve larvae (Kinne 1971, Mann \& Wolf 1983, Mann 1985, Scrope-Howe \& Jones 1986, Tremblay \& Sinclair 1988). Aggregation of sea scallop Placopecten magellanicus larvae in the area of the thermocline in the Bay of Fundy was reported by Tremblay \& Sinclair (1988). Scrope-Howe \& Jones (1986) reported movement of bivalve larvae into the chlorophyll maximum at night in locations in the western Irish Sea. The coincidence of temperature and/or salinity discontinuities with chlorophyll maxima or other potential food aggregations clearly emphasises the ecological significance of larval depth regulation in possibly optimising both dispersal and growth. In laboratory systems Carriker (1986) indicated that $C$. virginica larvae concentrate at the top of a salinity discontinuity and that the larger the magnitude of the salinity discontinuity, the more marked the concen- tration of larvae. Laboratory responses of C. virginica larvae to complete salinity changes within an experimental chamber have been reported by Hidu \& Haskin (1978), and Kennedy \& Van Heukelem (1986). Larvae increased their swimming rate when higher salinity water was added (e. g. from 7 to $14 \%$ salinity) and also when larval size increased (Hidu \& Haskin 1978). Kennedy \& Van Heukelem (1986) reported that a $0.4 \%$ salinity increase modified the geotactic response in $C$. virginica larvae from negative to positive and further stated that such larvae were capable of crossing both a $5 \%$ salinity and a $5{ }^{\circ} \mathrm{C}$ temperature discontinuity. Although Hidu \& Haskin (1978) reported that an increase in temperature increased the swimming rate of C. virginica larvae, Kennedy \& Van Heukelem (1986) found no effect of temperature on the larval behaviour.

The 3 mactrid species examined here occupy, in their adult life stage, habitats grading from brackish through estuarine to coastal oceanic. The responses of their larval forms are considered here in relation to adult distribution and this gradient. Since Spisula solidissima, Mulinia lateralis and Rangia cuneata larvae were examined in salinity ranges within their reported tolerances, it is tempting to suggest that larvae are capable, through depth regulation in response to salinity stratification, of maintaining themselves within specific salinity ranges and enhancing their chances of settlement within a salinity range conducive to adult survival. S. solidissima larvae remained in high salinity water in the experiments. This selective behaviour might confer some advantages in nature; however, these larvae are unlikely to encounter large salinity variations in the Middle Atlantic coastal zone where the water remains essentially unstratified (with respect to salinity but not temperature - see Bigelow 1933, Beardsley et al. 1976 and Williams \& Godshall 1977 for accounts of seasonal variation of physical variables in the Middle Atlantic region) during summer, when larvae are present in the water column (Tarnowski 1982, Mann 1985). M. lateralis larvae could use their apparent preference for discontinuities (haloclines in the field) or higher salinity water when swimming in partially mixed estuaries to avoid lower salinity, seawardflowing surface water. The relatively short planktonic period of this species might also be involved in the retention of these larvae along the estuary. Observed abundances of $R$. cuneata larvae in the discontinuity and $10 \%$ salinity layer suggest that larvae in nature would be transported toward the mouth of the estuary; however, high sinking rate, especially in the early stages, and a short larval period may offset the behavioural characteristic and aid in the retention of $R$. cuneata larvae in the low salinity zone of most partially mixed estuaries. 
Acknowledgements. This work was supported by the Council on the Environment of the Commonwealth of Virginia and was completed in partial fulfillment of the degree of M. A. by B. M. Campos. We thank Michael Castagna for encouragement and use of the Wachapreague Laboratory. The manuscript was improved by comments from George Grant, Morris Roberts $\mathrm{Jr}$ and 3 anonymous reviewers

\section{LITERATURE CITED}

Andrews, J. D. (1979). Pelecypoda: Ostreidae. In: Giese, A. C., Pearse, J. S. (eds.) Reproduction of marine invertebrates, Vol. 5. Academic Press, New York, p. 293-339

Andrews, J. D. (1983). Transport of bivalve larvae in James River, Virginia. J. Shellfish Res. 3 (1): 29-40

Beardsley, R. C., Boicourt, W. C., Hansen, D. V. (1976), Physical oceanography of the Middle Atlantic Bight, Middle Atlantic Continental Shelf and the New York Bight, Vol 2. Am. Soc. Limnol. Oceanogr., Lawrence, Kansas, p. 20-34

Bigelow, H. B. (1933). Studies of the waters on the continental shelf, Cape Cod to Chesapeake Bay, I, The cycle of temperature. Pap. phys. Oceanogr. Met. 2 (4), 135 p.

Boicourt, W. C. (1982), Estuarine larval retention mechanisms on two scales. In: Kennedy, V. S. (ed.) Estuarine comparisons. Academic Press, New York, p. 445-457

Cain, T. D. (1972). The reproductive cycle and larval tolerances of Rangia cuneata in the James River, Virginia. Ph.D. dissertation, Univ. of Virginia

Cain, T. D. (1973). The combined effects of temperature and salinity on embryos and larvae of the clam Rangia cuneata. Mar. Biol. 21: 1-6

Cain, T. D. (1975). Reproduction and recruitment of the brackish water clam Rangia cuneata in the James River, Virginia. Fish. Bull, U.S. 73 (2): 412-430

Calabrese, A. (1969). Individual and combined effects of salinity and temperature on embryos and larvae of the coot clam Mulinia lateralis. Biol. Bull. mar. biol. Lab., Woods Hole 137: 417-428

Carriker, M. R. (1951). Ecological observations on the distribution of oyster larvae in New Jersey estuaries. Ecol. Monogr. 21: 19-38

Carriker, M. R. (1961). Interrelation of functional morphology, behaviour and autecology in early stages of the bivalve Mercenaria mercenaria. J. Elisha Mitchell scient. Soc. 177: 168-242

Carriker, M. R. (1986). Influence of suspended particles on biology of oyster larvae in estuaries. Am. Malac. Bull., Spec. Edn 3: 41-49

Castagna, M., Chanley, P. (1973). Salinity tolerance of some marine bivalves from inshore and estuarine environments in Virginia waters on the western Mid-Atlantic coast. Malacologia 12 (1): 47-96

Castagna, M., Kraeuter, J. N. (1981). Manual for growing the hard clam Mercenaria mercenaria. Special Report in Applied Marine Science and Ocean Engineering No. 249. Virginia Institute of Marine Science

Chanley, M. H. (1981). Laboratory culture of marine bivalve molluscs. In: Committee on marine invertebrates (eds.) Marine invertebrates. National Academic Press, Washington, D. C., p. 233-249

Chanley, P. (1965). Larval development of the brackish water mactrid clam, Rangia cuneata. Chesapeake Sci. 6 (4): 209-213

Chia, F.-S., Buckland-Nicks, J., Young, J. (1984). Locomotion of marine invertebrate larvae; a review. Can. J. Zool. 62: $1205-1222$

Cragg, S. M. (1980). Swimming behaviour of the larvae of Pecten maximus (L.) (Bivalvia). J. mar. biol. Ass. U. K. 60: 551-564

Cragg, S. M., Gruffydd, L. D. (1975). The swimming behaviour and pressure responses of the veliconcha larvae of Ostrea edulis L. In: Barnes, H. (ed.) Proc. 9th Europ. mar. biol. Symp. Aberdeen University Press, Aberdeen p. 43-57

Culliney, J. L., Boyle, P. J., Turner, R. D. (1975). New approaches and techniques for studying bivalve larvae. In: Smith, W., Chanley, M. (eds.) Culture of marine invertebrate animals. Plenum Press, New York, p. 257-271

Dowdy, J. H., Wearden, S. (1983). Statistics for research. John Wiley and Sons, New York

Dupuy, J. L., Windsor, N. T., Sutton, C. E. (1977). Manual for design and operation of an oyster seed hatchery for the American oyster Crassostrea virginica. Special Rep. in Applied Marine Science and Ocean Engineering, No. 142, Virginia Institute of Marine Science

Franz, D. R., Merrill, A. S. (1980). Molluscan distribution patterns on the Continental Shelf of the Middle Atlantic Bight (Northwest Atlantic). Malacologia 19 (2): 209-225

Gainey, Jr, L., Greenberg, M. (1977). Physiological basis of the species abundance-salinity relationship in molluscs: a speculation. Mar. Biol. 40: 41-49

Gallager, S. M. (1985). Buoyancy regulation and swimming energetics in larvae of Bankia gouldi (Bartsch) (Teredinidae: Bivalvia). Abstr. 77th Annual Meeting Natl. Shellfish. Ass., p. 8

Gallager, S. M., Mann, R., Sasaki, G. C. (1986). Lipid as an index of growth and viability in three species of bivalve larvae. Aquaculture 56: 81-103

Goldberg, R. (1980). Biological and technological studies on the aquaculture of yearling surf clams. Part 1: Aquacultural production. Proc. natl. Shellfish. Ass. 70: 55-60

Guillard, R. R. (1983). Culture of phytoplankton for feeding marine invertebrates. In: Berg, C. J. (ed.) Culture of marine invertebrates. Hutchinson Ross Publ., Pennsylvania, p. 108-132

Harder, W. (1968). Reaction of plankton organisms to water stratification. Limnol. Oceanogr. 13: 156-168

Hidu, H., Haskin, H. (1978). Swimming speeds of oyster larvae Crassostrea virginica in different salinities and temperatures. Estuaries 1 (4): 252-255

Isham, L. B., Tierney, J. Q. (1953). Some spects of the larval development and metamorphosis of Teredo (Lyrodus) pedicellata DeQuatrefages. Bull. mar. Sci. Gulf Carib. 2 (4): $574-589$

Kennedy, V. S., Van Heukelem, W. F. (1986). Responses to environmental factors by larval oysters (Crassostrea virginica). Am. Malac. Bull. 4 (1): 101

Kennedy, V. S., Roosenburg, W. H., Zion, H. H., Castagna, M. (1974). Temperature-time relationships for survival of embryos and larve of Mulinia lateralis (Mollusca: Bivalvia). Mar. Biol. 24: 137-145

Kinne, O. (1971). Marine ecology, Vol. 1, Part II. Wiley, London, p. 821-996

Korringa, P. (1941). Experiments and observations on swarming, pelagic life and setting in the European flat oyster Ostrea edulis L. Arch. Néerl. Zool. 5: 1-249

Korringa, P. (1952). Recent advances in oyster biology. Q. Rev. Biol. 27: 266-308; 339-365

Kunkle, D. E. (1957). The vertical distribution of larvae in Delaware Bay. Proc, natl. Shellfish. Ass. 48: 90-91

Lance, J. (1962). Effects of water of reduced salinity on the 
vertical migration of zooplankton. J. mar, biol. Ass. U. K. 42: $131-154$

LaSalle, M. W., de la Cruz, A. A. (1985). Species profiles: life history and environmental requirements of coastal fishes and invertebrates (Gulf of Mexico). Common Rangia. US Fish Wildl. Serv. Bull. Rep. 82 (11.31) US Army Corps of Engineers TR EL-82-4, 18 p.

Lippson, A. J., Lippson, R. L. (1984). Life in Chesapeake Bay. John Hopkins University Press, Baltimore

Lucas, A., Chebab-Chalabi, L., Aldana Aranda, D. (1986). Passage de l'endotrophie a l'exotrophie chez les larves de Mytilus edulis. Oceanol. Acta 9 (1): $97-103$

Mann, R. (1985). Seasonal changes in the depth distribution of bivalve larvae on the Southern New England Shelf. J. Shellfish Res. 5 (2): 57-64

Mann, R. (1986a). Sampling of bivalve larvae. In: Jamieson, G. S., Bourne, N. (eds.) North Pacific Workshop on stock assesment and management of invertebrates. Spec. Publ. Can. Fish. Aquat. Sci. 92: 107-116

Mann, R. (1986b). Arctica islandica (Linne) larvae: active depth regulators or passive particles. Am. Malac. Bull. Spec. Edn 3: 51-57

Mann, R. (1988). Distribution of bivalve larvae at a frontal system in the James River, Virginia. Mar. Ecol. Prog. Ser. 50: $29-44$

Mann, R., Wolf, C. C. (1983). Swimming behaviour of larvae of the ocean quahog Arctica islandica in response to pressure and temperature. Mar. Ecol. Prog. Ser. 13: 211-218

Manning, J. H., Whaley, H. H. (1954). Distribution of oyster larvae and spat in relation to some environmental factors in a tidal estuary. Proc. natl. Shellfish. Ass. 45: 56-65

Mileikovsky, S. A. (1973). Speed of active movement of pelagic larvae of marine bottom invertebrates and their ability to regulate their vertical position. Mar. Biol. 23: $11-17$

Nelson, T. C. (1953). Some observations on the migrations and setting of oyster larvae. Proc. natl. Shellfish. Ass. 43: 99-104

Nelson, T. C. (1955). Observations on the behaviour and distribution of oyster larvae. Proc. natl. Shellfish. Ass. 45: 23-28

Norusis, M. J. (1985). SPSSX advanced statistics guide. McGraw-Hill, New York

Pritchard, D. W. (1952). Distribution of oyster larvae in relation to hydrographic conditions. Proc. Caribb. Fish. Inst. Nov. 1952 , p. $1-10$

Quayle, D. B. (1969). Pacific oyster culture in British Columbia. Bull. Fish. Res. Bd Can. 169: 1-192

Roosenburg, W. H., Wright, D. A., Castagna, M. (1984). Thermal tolerance by embryos and larvae of the surf clam Spisula solidissima. Environ. Res. 34: 162-169

Scheltema, R. S. (1986). On dispersal and planktonic larvae of benthic invertebrates: an eclectic overview and summary of problems. Bull. mar. Sci. 39 (2): 290-322

This article was presented by Dr G. C. Harding, Dartmouth, N.S., Canada
Scrope-Howe, S,, Jones, D. A. (1986). The vertical distribution of zooplankton in the western Irish Sea. Estuar. coast. Shelf Sci. 22: 785-802

Seliger, H. H., Boggs, J. A., Rivkin, R. B., Biggley, W. H., Aspden, K. R. (1982). The transport of oyster larvae in an estuary. Mar. Biol. 71: 57-72

Sokal, R. R., Rohlf, F. J. (1981). Biometry, 2nd edn. W. H. Freeman and Co., San Francisco

Stancyk, S. E., Feller, R. J. (1986). Transport of non-decapod invertebrate larvae in estuaries: an overview. Bull. mar. Sci. 39 (2): 257-268

Tarnowski, M. L. (1982). Temporal distribution of surf clam larvae off southern New Jersey. J. Shellfish. Res. 2 (1): 108

Theroux, R. B., Wigley, R. L. (1983). Distribution and abundance of East Coast bivalve mollusks based on specimens in the National Marine Fisheries Service Wood Hole Collection. NOAA Tech. Rep. 768, 172 p.

Thorson, G. (1950). Reproductive and larval ecology of marine bottom invertebrates. Biol. Rev. 25: 1-45

Tremblay, M. J., Sinclair, M. M. (1988). The vertical and horizontal distribution of sea scallop (Placopecten magellanicus) larvae in the Bay of Fundy in 1984 and 1985. J. Northw. Atl. Fish. Sci. 8: 43-54

Vogel, S. (1981). Life in moving fluids. Willard Grant Press, Boston

Walne, P. R. (1965). Observations on the influence of food supply and temperature on the feeding and growth of the larvae of Ostrea edulis L. Fish. Invest. Lond. Ser 2, 24 (1): $1-45$

Williams, R. G., Godshall, P. A. (1977). Summarization and interpretation of historical physical oceanographic and meteorological information for the Mid Atlantic Bight. NOAA Center for Experimental Design and Data Analysis, Final Report to Bureau of Land Management, Oct 1977, $306 \mathrm{pp}$.

Winet, H. (1973). Wall drag on free moving ciliated microorganisms. J. exp. Biol. 59: 753-766

Wood, L., Hargis Jr, W. J. (1971). Transport of bivalve larvae in a tidal estuary. In: Crisp, D. J. (ed.) Proc. 4th Europ. mar. biol. Symp. Cambridge University Press., Cambridge, p. 29-44

Wright, D. A., Kennedy, V. S., Roosenburg, W. H., Castgna, M., Mihursky, J. A. (1983). Temperature tolerance of embryos and larvae of five bivalve species under simulated power plant entrainment conditions: a synthesis. Mar. Biol. 77: 271-278

Zar, J.H. (1984). Biostatistical analysis, 2nd edn. Prentice Hall, New Jersey

Zinsmeister, W. J., Emerson, W. K. (1979). The role of passive dispersal in the distribution of hemipelagic invertebrates, with examples from the tropical Pacific Ocean. Veliger 22 (1): $32-40$

Manuscript first received: April 27, 1990

Revised version accepted: September 14, 1990 